
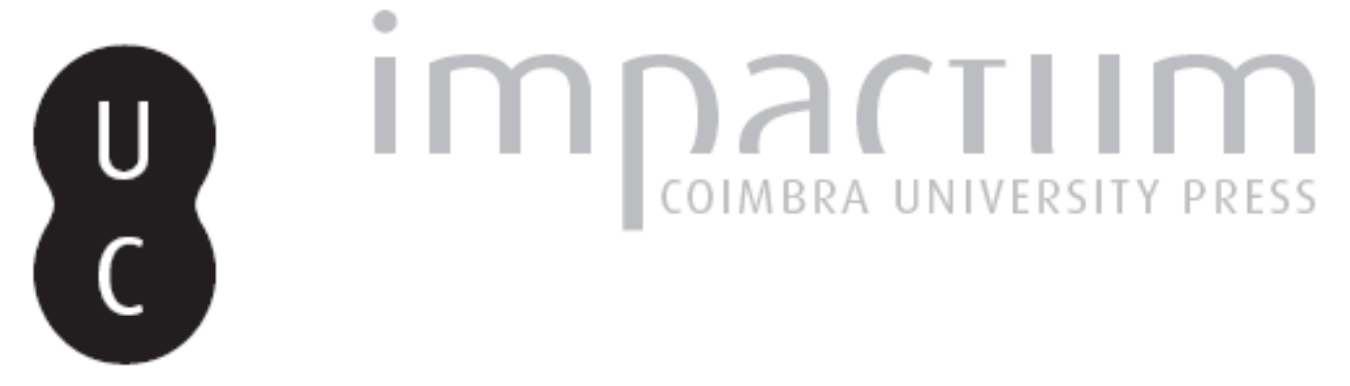

\title{
A securitização da cooperação para o controle de fronteiras da União Européia
}

\section{Autor(es): $\quad$ Ferreira, Luciano Vaz}

Publicado por: Universidade Católica de Petrópolis

URL persistente:

URI:http://hdl.handle.net/10316.2/33776

DOI:

DOI:http://dx.doi.org/10.14195/2175-0947_3-2_3

Accessed : $\quad$ 26-Apr-2023 16:21:42

A navegação consulta e descarregamento dos títulos inseridos nas Bibliotecas Digitais UC Digitalis, UC Pombalina e UC Impactum, pressupõem a aceitação plena e sem reservas dos Termos e Condições de Uso destas Bibliotecas Digitais, disponíveis em https://digitalis.uc.pt/pt-pt/termos.

Conforme exposto nos referidos Termos e Condições de Uso, o descarregamento de títulos de acesso restrito requer uma licença válida de autorização devendo o utilizador aceder ao(s) documento(s) a partir de um endereço de IP da instituição detentora da supramencionada licença.

Ao utilizador é apenas permitido o descarregamento para uso pessoal, pelo que o emprego do(s) título(s) descarregado(s) para outro fim, designadamente comercial, carece de autorização do respetivo autor ou editor da obra.

Na medida em que todas as obras da UC Digitalis se encontram protegidas pelo Código do Direito de Autor e Direitos Conexos e demais legislação aplicável, toda a cópia, parcial ou total, deste documento, nos casos em que é legalmente admitida, deverá conter ou fazer-se acompanhar por este aviso.

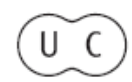



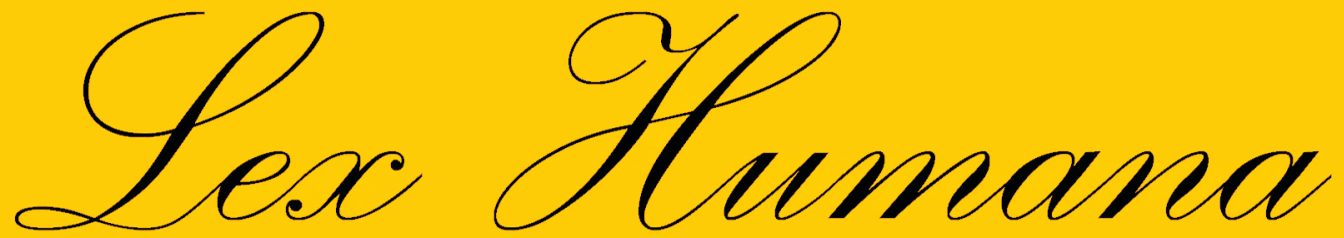

Revista do Programa de Pós-Graduação em Direito da UCP

ISSN(e) 2175-0947

Universidade Católica de Petrópolis Rua Benjamin Constant, 213 - Petrópolis - Centro CEP 25610-130

Tel: (24) 2244-4000 E-mail: lexhumana@ucp.br 


\section{A SECURITIZAÇĀO DA COOPERAÇĀO PARA O CONTROLE DE FRONTEIRAS DA UNIÁO EUROPÉIA ${ }^{1}$}

Luciano Vaz Ferreira ${ }^{2}$

Resumo: Frente ao medo de fragmentação, que poderia conduzir a uma nova guerra, a Europa implementou um intenso processo de integração, que culminou na formação da Uniáo Européia, uma organização supranacional. A reduçáo das barreiras econômicas e políticas que permitiram a integração européia e a formação de uma identidade comum, também direcionaram a política comunitária para o controle das fronteiras externas. Nesse cenário, a imigração ilegal é encarada como uma ameaça à integração européia, passando a ser tratada pelos mecanismos de segurança. O presente artigo tem como objetivo estudar o processo de securitização do controle de fronteiras na União Européia, especialmente quanto à evolução das instituiçóes comunitárias e a criação de uma agência européia de controle de fronteiras, a FRONTEX. Como método, optou-se por revisáo bibliográfica de material produzido por autores europeus. A base teórica será o trabalho de Buzan e Waever sobre "Complexos Regionais de Segurança” (Regions and Powers: The Structure of International Security).

Palavras-chave: União Européia; Securitização; Controle de Fronteira; Imigraçáo.

Abstract: Due to fear of fragmentation that could lead to a new war, Europe has implemented an intensive integration process, which culminated in the formation of the European Union, a supranational organization. The reduction of economic and political barriers that have allowed the european integration and the formation of a common identity, also directed the community policy for the control of external borders. In this scenario, illegal immigration is seen as a threat to european integration, starting to be handled by security mechanisms. This article aims to study the process of securitization of border control in the European Union, especially regarding the evolution of the community institutions and the creation of a european border control agency, the FRONTEX. As a method, we chose literature review of material produced by european authors. The theoretical basis is the work of Buzan and Waever on "Regional Security Complex" ("Regions and Powers: The Structure of International Security").

Keywords: European Union; Securitization; Border Control; Immigration.

\footnotetext{
${ }^{1}$ Artigo recebido em 26/09/2011 e aprovado para publicação pelo Conselho Editorial em 19/11/2011.

${ }^{2}$ Doutorando em Estudos Estratégicos Internacionais da Universidade Federal do Rio Grande do Sul, UFRGS, Brasil. Currículo Lattes: http://lattes.cnpq.br/3631125025276911. E-mail: lvazferreira@gmail.com.
} 


\section{Introdução}

Olhando para o comportamento recente da União Européia (UE), observa-se que, nas últimas décadas, a instituição está empreendendo uma verdadeira operação de guerra contra a imigração ilegal, especialmente no contexto pós-onze de setembro. Pela forma e intensidade que essas ações estão sendo realizadas, é imperativo estudar as razóes que motivam essa postura da entidade comunitária.

Tomando por base a teoria de Buzan e Waever, o objetivo do presente estudo é analisar os processos de securitização do "Complexo Regional de Segurança Europeu" (CRSE), de modo a entender as dinâmicas de segurança que envolvem o controle dos fluxos de pessoas na UE.

No primeiro ponto será abordada a formação do CRSE, com objetivo de estabelecer as suas características, vinculando-se principalmente ao movimento de centralizaçáo do complexo na forma da UE. No segundo ponto, direciona-se à análise das questóes de imigração como problema de segurança, bem como os processos institucionais comunitários que internalizaram a securitização da liberdade de locomoção na UE. Ao final, serão apresentados alguns exemplos de práticas comunitárias e nacionais que envolvem o controle de fronteiras.

\section{A Natureza do Complexo Regional de Segurança Europeu}

\subsection{A Formaçáo do Complexo Europeu}

A formação do "Complexo Regional de Segurança Europeu" (CRSE) é de origem remota, reportando-se ao movimento expansionista do Império Romano. Apresentando-se, inicialmente, como uma ordem centralizada, foi substituída, após o declínio da civilização romana e as invasões bárbaras, por um sistema anárquico, composto por diversos Estados, que 
durou séculos ${ }^{3}$. Esse padrão é repetido ao longo da evoluçáo do complexo europeu, em uma espécie de "movimento pendular", que alterna momentos de anarquia e tentativas de retorno a um sistema centralizado ${ }^{4}$.

Foi durante o período anárquico europeu que se desenvolveu um mecanismo securitário capaz de equilibrar as relaçóes de força e impedir o caos completo: o clássico "sistema de equilíbrio de poder". Toda vez que uma potência européia, de forma ambiciosa, ameaçasse conquistar e anexar um território vizinho, os Estados aliar-se-iam para resistir ao ataque, evitando-se a ascensão de uma nação expansionista capaz de subjugar os demais. Sustentada em frágeis alianças, essa dinâmica era causadora de uma constante alternância entre guerra e paz, o que transformava o território europeu em uma eterna região de conflitos.

Conforme Buzan e Waever, o período que compreende de 1500 a 1945 é marcado pela expansão do sistema europeu além de suas fronteiras. O protagonismo das naçóes européias permitiu o uso do seu poder político, econômico e militar em escala global, suprimindo o desenvolvimento de complexos de segurança locais e independentes nas regióes colonizadas. $\mathrm{O}$ palco do complexo de segurança europeu passou a ser o mundo 5 .

O CRSE foi drasticamente modificado pelos eventos do Século XX, passando a ter seus contornos atuais definidos após enfrentar duas guerras mundiais, a bipolaridade da Guerra Fria e a reorganização da ordem mundial com o declínio da União Soviética.

O cenário de destruição européia na Segunda Guerra Mundial permitiu a ascensão dos dois grandes vencedores do conflito, Estados Unidos e União Soviética, no jogo de poder internacional, que passaram a rivalizar entre si. A Europa, antes centro exclusivo de poder, é eclipsada pelas dinâmicas de segurança da Guerra Fria, tornando-se um dos fronts do conflito.

\footnotetext{
3 BUZAN, Barry; WAEVER, Ole. Regions and Powers: The Structure of International Security. Cambridge: Cambridge University Press, 2003, p. 345.

${ }^{4}$ Como evidência da ciclicidade histórica, menciona-se as tentativas frustradas de centralização empreendidas pelo Sacro Império Romano Germânico, pela França napoleônica e pela Alemanha nazista, que podem ser caracterizadas, de acordo com suas particularidades, como projetos de retorno a uma Europa centralizada.

${ }^{5}$ BUZAN, Barry; WAEVER, Ole. Op. Cit., p. 15.
} 
Um novo contexto foi estabelecido pela presença dos Estados Unidos no cerne do CRSE, que objetivavam conter o avanço soviético na regiáo. Acreditando que as instabilidades políticas, econômicas e sociais poderiam tornar a Europa vulnerável ao modelo comunista, o governo norte-americano lançou o Plano Marshall, plano de recuperaçáo econômica e reconstruçâo das naçóes européias. Seguindo essa mesma estratégia, criou-se, em 1949, a Organização do Tratado do Atlântico Norte (OTAN), aliança militar que formalizou a posição dos EUA como garantidor da segurança européia.

Nesses acontecimentos, duas conseqüências importantes podem ser observadas. Primeiro, a inserção dos Estados Unidos criou uma dinâmica de segurança contínua, fazendo com que muitas vezes a agenda de norte-americana marcasse presença no continente.

Segundo, os processos econômicos desencadeados pelo Plano Marshall reconfiguraram o CRSE de maneira única, deixando de ser um sistema não hierárquico para torná-lo centralizado novamente. Porém, essa centralização não foi estabelecida de maneira unipolar, com uma nação impondo sua força sobre as outras, mas "baseada em instituiçóes", conforme classificação de Buzan e Waever ${ }^{6}$, diferente de qualquer outro complexo regional de segurança. O conjunto de instituições é representado pela União Européia (UE), organização supranacional de caráter regional.

\subsection{A União Européia}

A origem da União Européia está na discussão, a partir da década de 50, sobre a criação de uma organização regional cujo objetivo seria regular conjuntamente a produçáo de aço e carvão, de modo a superar uma crise de superprodução prejudicial à reconstrução européia.

No entanto, em uma análise mais apurada, constata-se que existiam outras razóes além da econômica para a centralizaçáo. Não se pode olvidar que o processo de integraçáo

\footnotetext{
${ }^{6}$ BUZAN, Barry; WAEVER, Ole. Op. Cit., p. 62.
} 
comunitária iniciou com os esforços do governo francês e alemão, históricos rivais, demonstrando o simbolismo do ato.

Nas palavras de Robert Schuman, ministro das exteriores da França na época e considerado um dos pais do projeto, a cooperação entre as naçóes da Europa "requer a eliminação da histórica oposição entre França e Alemanha", sendo a escolha pela partilha do carvão e aço, fonte principal na produção de armamentos, por meio de uma autoridade supranacional se dá para transformar a guerra entre essas nações "não somente impensável, mas materialmente impossível”.

Isso demonstra a grande motivação securitária para a formação da instituição européia. Buzan e Waever apontam que a centralização do $\mathrm{CRSE}^{8}$ foi motivada pelo medo de retornar ao antigo esquema de equilíbrio de poder, que implicava em rivalidades e guerras constantes?. Sabe-se que o pesado custo desse modelo ultrapassou todos os limites com o horror proporcionado pela Segunda Guerra Mundial. Nesse passo, integração européia é encarada como uma "necessidade" para a própria sobrevivência da Europa, ameaçada tanto pelo retorno ao passado como pelo projeto comunista.

Sendo assim, em 1951, foi criada, em Paris, a "Comunidade Européia do Carvão e do Aço”. O próximo passo do degrau comunitário foi dado com a assinatura do Tratado de Roma (1957), que criou a "Comunidade Econômica Européia”, e a "Comunidade Européia de Energia Atômica”. Nas décadas seguintes a integração comunitária foi expandida para englobar outros $\operatorname{Estados}^{10}$

\footnotetext{
7 SCHUMAN, Robert. Declaration of 9 May 1950. Disponível em: < http://europa.eu/abc/symbols/9may/decl_en.htm>. Acesso em: 20.06.2011.

${ }^{8}$ Ao longo do texto será utilizada a expressão "União Européia" (UE) também como sinônimo para "Complexo Regional de Segurança Europeu" (CRSE). Ainda que nem todos os países europeus sejam partes da UE (como Islândia, Noruega e Suíça, bem como microestados europeus), o autor entende que há integração dessas regiôes no espaço securitário da UE por meio das políticas do Acordo de Schengen (políticas comuns de concessão de vistos, redução de fronteiras internas e controle das fronteiras externas). Da mesma forma, a constante ampliação da UE em direção ao Leste Europeu é responsável pelas mudanças nos complexos regionais vizinhos, fazendo com que naçôes do complexo dos Bálcâs e da Rússia passem a fazer parte do CRSE. Por tudo isso, entende-se que as áreas da UE (incluindo o "Espaço Schengen") e do CRSE coincidem.

${ }^{9}$ BUZAN, Barry; WAEVER, Ole. Op. Cit., p. 57.

${ }^{10}$ A UE enfrentou vários movimentos de expansão ao longo da sua evolução. Junto aos membros fundadores
} 
O Ato Único Europeu (1986), documento que previu a criação de um "mercado comum”, estabeleceu como nova meta, além das articulaçôes meramente econômicas, a integração política, trazendo para a agenda comunitária outros assuntos e problemas. A idéia era transformar a Europa em uma região de livre circulaçáo de mercadorias, capitais, fatores de produção, serviços e trabalhadores.

Tal processo culminou, na formalização, em 1992, da União Européia, pelo Tratado de Maastricht. A estrutura da instituição foi organizada em três grandes temas, divididos em "pilares": o pilar comunitário, de caráter supranacional, que trata de questóes econômicas; o pilar de política externa e segurança, intergovernamental; e o pilar de justiça e assuntos internos, também intergovernamental.

A diferença na classificação entre o caráter supranacional e intergovernamental reside no grau de integração na área, pois no primeiro as decisóes são tomadas pela maioria dos Estados membros, enquanto na segunda a aprovaçáo ocorre apenas com a unanimidade. De qualquer sorte, como pode ser observado, Maastricht, coloca, oficialmente, na agenda comunitária, as questóes de segurança, o que demonstra o movimento de securitizaçáo na instituição de integração.

A criação da UE marca a tentativa de uma formação de uma "comunidade de segurança”, conforme terminologia de Karl Deutsch. Trata-se de um grupo de Estados, ligados por um "senso de comunidade", que se comprometem em resolver os seus problemas sociais por processos institucionalizados, sem recorrer à força física em larga escala. Em outras palavras, são regiôes as quais o uso da guerra entre os Estados vizinhos tornou-se inconcebível ${ }^{11}$.

(França, Alemanha, Holanda, Bélgica, Luxemburgo e Itália), somaram-se Reino Unido, Irlanda e Dinamarca (1973), Grécia (1981), Portugal e Espanha (1986), Áustria, Suécia e Finlândia (1995), Malta, Chipre, Estônia, Lituânia, Letônia, Polônia, República Checa, Eslováquia, Eslovênia e Hungria (2004), Bulgária e Romênia (2007), totalizando, na contagem atual, vinte e sete membros.

${ }^{11}$ DEUTSCH, Karl, et al. Political Community and the North Atlantic Area. In: International Political Communities: An Anthology. New York: Doubleday and Company, 1966, p. 02. 
Deutsch classifica as comunidades de segurança em duas classes: as pluralísticas, em que os Estados mantém a sua independência política; e as amalgamadas, em que há união das partes em um governo comum, nos moldes de Estado federado ${ }^{12}$. No caso da União Européia, seus Estados membros mantém a sua soberania dentro da instituição, no entanto, os processos de integração também a aproxima, por vezes, do modelo de comunidade amalgamada, tornando-a sui generis dentro dessa classificação.

Com o fim da Guerra Fria, novos contornos foram dados ao CRSE. Uma vez liberta da dinâmica da segurança bipolar, a UE passou a desenvolver os seus próprios processos de securitização. Com a UE, não há espaço para formas tradicionais de ameaça que envolvem Estado contra Estado, passando, assim, para a securitização de assuntos não militares. Nesse cenário, um dos assuntos mais proeminentes nas últimas décadas diz respeito à securitização no controle de fronteira e de política de imigração.

\section{A Securitização da Imigraçáo e do Controle de Fronteiras na Uniāo Européia}

\section{1 A Imigraçáo como um problema de segurança}

Partindo-se do suposto de que se trata de segurança quando há uma ameaça (real ou retórica) a um objeto, de modo a justificar o uso de medidas extraordinárias para lidar com o problema $^{13}$, entende-se que os movimentos populacionais podem ser inseridos nesse conceito, especialmente no contexto da UE.

Conforme Bali, de acordo com o clássico direito de soberania, os Estados possuem a jurisdição dentro de suas fronteiras, exercendo a plena autoridade em definir quem irá entrar em seu território. São operados sistemas de controle de fronteiras, com políticas de como será

\footnotetext{
${ }^{12}$ Ibid., loc. cit.

${ }^{13}$ RUDZIT, Gunther. O debate teórico em segurança internacional: mudanças a frente do terrorismo? Civitas, v. 5, n. 2, Porto Alegre, jul. / dez. 2005, p. 308.
} 
o ingresso no país, por quanto tempo e sob quais condiçóes. As decisóes podem ser baseadas em vários critérios, como habilidades profissionais necessárias para o desenvolvimento da economia nacional e semelhanças culturais ou étnicas com a população local ${ }^{14}$.

A autora apresenta de modo exemplificativo algumas razóes para que os fluxos migratórios possam ser tratados como um assunto de segurança. Primeiro, a migração desafia a noção de identidade nacional, composta classicamente por um povo de história, língua, religião e cultura compartilhadas. Segundo, o engajamento de grupo de imigrantes em questôes políticas também pode ajudar a deteriorar as relaçôes entre o Estado de origem e o Estado receptor. Terceiro, em muitas sociedades os imigrantes são vistos como um fardo econômico, dependentes de políticas sociais (como moradia, educação, transporte e saúde). Nesse contexto de degradação social, também podem ser encarados como criminosos ou condutores de doenças infecciosas ${ }^{15}$.

A securitização da imigração passou a ocupar lugar de maior destaque com a dinâmica da "guerra contra o terror" (2001). Não se pode esquecer que os participantes do ataque terrorista eram imigrantes, temporários ou ilegais. Isso serviu de justificativa para o governo norte-americano integrar seus serviços de imigração ao sistema de segurança ${ }^{16}$. A referência às políticas imigratórias pelo Ato Patriótico (US Patriotic Act), diploma legislativo que derrogou uma série de direitos fundamentais em prol da luta contra o terrorismo, e a absorção do tema pela pasta do Departamento de Segurança Doméstica (US Department of Homeland Security) apresentam-se como provas.

No contexto da UE, existe um discurso recorrente de vulnerabilidade em relação à questão da imigração. Três espécies de fluxos migratórios são os principais objetos de securitização:

\footnotetext{
${ }^{14}$ BALI, Sita. Population Moviments. In: WILLIAMS, Paul D. Security Studies: an introduction. New York: Routledge, 2005, p. 472.

${ }^{15}$ BALI, Sita. Op. Cit.,p. 476-478.

${ }^{16}$ Ibid., p. 471.
} 
Primeiro, com o fim da influência soviética, as nações ao longo da borda da UE tornaram-se novas democracias e mercados candidatos à integração regional. Sendo assim, a UE expandiu-se em direção do Leste Europeu, absorvendo seus problemas de segurança.

Buzan e Waever entendem que a expansão pode ser um elemento de insegurança para UE. A memória ainda viva da Guerra dos Bálcâs representa a possibilidade de uma guerra na Europa. Outra questão é a diluição dos poderes da aliança Franco-Germânica na UE, que passa a ser menos dominante com a ascensão de outras naçóes ${ }^{17}$.

Segundo, a Europa, enquanto historicamente sensível à securitização norte-americana (conforme já comentado), internalizou a guerra contra o terror. Trata-se de uma situação de "macro-securização" que afetou diretamente às políticas migração e liberdade na UE. Os atentados de Madrid (11 de março de 2004) e Londres (7 de julho de 2005), contribuíram para a formação dessa dinâmica de segurança no continente.

Conforme Bali, há aproximadamente 20 milhóes de muçulmanos na Europa, sendo que a França possui os maiores números (cerca de $9 \%$ de sua populaçáo). Comunidades muçulmanas estabelecidas há décadas e integradas à sociedade local, no Reino Unido, França e Dinamarca, passaram a ser, na luz da guerra global contra o terror, tratadas como ameaça, tornando-se foco de tensão ${ }^{18}$.

Terceiro, a delicada situação dos refugiados econômicos, especialmente oriundos da África Subsariana que ingressam ilegalmente no território da UE em busca de novas oportunidades.

A presença de outras culturas no continente europeu, com religióes, etnias, línguas e condições econômicas diferentes, é encarada como uma ameaça a ser securitizada por que interfere diretamente na base do processo de integraçáo: a formação de uma identidade européia. É visto como um risco de fragmentação, que abalaria a própria existência da UE.

O "Estado de bem estar social europeu" é considerado como ameaçado, quando os recursos estatais são destinados para subsidiar despesas com estrangeiros, carentes de políticas

\footnotetext{
${ }^{17}$ BUZAN, Barry; WAEVER, Ole. Op. Cit., p. 357.

${ }^{18}$ BALI, Sita. Op.Cit., p. 478.
} 
públicas. Tal situação permite o surgimento de regimes xenófobos na Europa, que defendem o endurecimento das políticas migratórias ${ }^{19}$.

Como resultado, Bigo entende que o processo de securitização na UE pode levar a criaçấo de uma fortaleza européia, com fronteiras militarizadas e baseada em uma política racista de "guerra contra a imigração". Nesse cenário, o imigrante é visto como impossível de ser integrado socialmente, podendo a qualquer momento ser expulso, de acordo com as necessidades econômicas da $\mathrm{UE}^{20}$.

\subsection{A Institucionalizaçáo da Securitizaçáo do Controle de Fronteiras}

A administração dos fluxos interestatais sempre foi um desafio para a integração da UE. Não se pode esquecer que base ideológica da UE está ligada ao liberalismo econômico, que prega a livre circulação de recursos, para que sejam mais eficientemente alocados. Logo, o sucesso do processo comunitário, nesses moldes, depende da liberdade de movimentaçáo transfronteiriça, que passa a ser assegurada institucionalmente.

Desde a criação da Comunidade Econômica Européia já havia previsão de liberdade de locomoção dos trabalhadores (art. 48, $\$ 1^{\circ}$ ). Com o avanço do processo de integraçáo em direção da constituiçáo de um mercado comum, o conceito expandiu-se para liberdade de pessoas em sentido amplo, que passou a ser assegurada nos documentos seguintes ${ }^{21}$.

Nesse cenário, desenvolveu-se o conceito europeu de "fronteira interna" e "externa": a interna é aquela que divide os países membros, enquanto a externa separa a zona da UE de terceiros países. Dentro do modelo de integração europeu, o controle excessivo das fronteiras

\footnotetext{
${ }^{19}$ Ibid., loc. cit.

${ }^{20}$ BIGO, Didier. Immigration Controls and Free Movement in Europe. International Review of The Red Cross, v. 91, n. 875, Genebra, set. 2005, p. 589.

${ }^{21}$ ATGER, Anaï Faure. The Abolition of Internal Border Checks in an Enlarged Schengen Area Freedom of movement or a web of scattered security checks? Research paper number eight. Disponível em: <www.ceps.eu>. Acesso em 20.06.2011, p. 03.
} 
internas, que gera custos de transação, passou a ser encarado como uma barreira ao livre comércio e óbice para a construção de um mercado único ${ }^{22}$.

Já a manutenção da fronteira externa do bloco enfrenta a questão da imigraçáo ilegal, agravada por dois fatores: o desenvolvimento econômico da UE, tornando-a atrativa para o refugiado econômico; e a expansão da UE em direção ao Leste Europeu e Mediterrâneo, que a aproxima de zonas de instabilidade. Aqui, ao contrário das barreiras internas que foram amenizadas, houve reforço no controle da fronteira externa ${ }^{23}$.

Apesar de todo o discurso econômico, as práticas comunitárias operacionalizaram um intenso processo de securitizaçáo da liberdade de locomoção, tanto do ponto de vista interno quanto externo, como será visto a seguir. Nos anos que seguiram a estruturação da integração regional desenvolveu-se um pesado aparato de segurança, composto pela proliferação de agências de inteligência e segurança comunitárias.

O início desse processo deu-se com a assinatura, em 1985, do "Acordo de Schengen". O tratado internacional possuía o objetivo de reduzir o controle de fronteiras internas entre os Estados europeus ao mesmo tempo em que estabelecia o controle comum da fronteira externa, por meio da harmonização da legislação sobre matéria e cooperação entre autoridades de fiscalização fronteiriça ${ }^{24}$.

Pela dificuldade de se atingir a unanimidade sobre a matéria, que envolve diretamente a soberania dos países, o acordo foi desenvolvido, primeiramente, fora do ambiente comunitário, com a adesão de apenas de Bélgica, Holanda, Luxemburgo, França e Alemanha. Nos anos posteriores, o Schengen foi incorporado no acervo comunitário, fazendo com que praticamente todos os integrantes da UE fizessem parte do sistema. Apenas Reino Unido e Irlanda optaram por não participar. Bulgária, Romênia e Chipre, por sua vez, estão em vias de implementação. Aderiram ao acordo, inclusive, Estados europeus não membros da UE: Suiça, Noruega, Islândia e alguns microestados da região.

\footnotetext{
${ }^{22}$ BERTOZZI, Stefano. Schengen: Achievements and Challenges in Managing an Area Ecompassing 3.6 million $\mathrm{km}^{2}$. Disponível em: <www.ceps.eu>. Acesso em 20.06.2011, p. 01.

${ }^{23}$ BIGO, Didier. Op.Cit., p. 580.

${ }^{24}$ BERTOZZI, Stefano. Op. Cit., p. 4.
} 
Com Schengen, há um controle mínimo para entrada e saída na UE de cidadãos europeus e uma fiscalizaçáo minuciosa para os oriundos de terceiros países. Já na fronteira interna, são abolidos os tradicionais postos de fronteira, permitindo-se a livre circulação de europeus e nacionais de outros países que ingressaram legalmente na UE.

Criou-se também um banco de dados virtual chamado de "Schengen Information System" (SIS), que mantém informações sobre pessoas e bens. Com ele, os Estados podem informar seus vizinhos sobre viajantes não europeus classificados como ameaças à segurança pública, conforme critérios nacionais. Como conseqüência, essas pessoas poderão ter a entrada negada em qualquer território da UE. Atualmente está sendo elaborada uma segunda versão do sistema ${ }^{25}$.

Nas décadas posteriores, observou-se um movimento de crescente institucionalização comunitária do controle de fronteiras, principalmente atrelada ao exercício de força policial, o que demonstra o caráter securitizador do processo. No Tratado de Maastricht (1992) agruparam-se os problemas referentes a asilo, imigração, trânsito de pessoas, cooperaçáo policial e judicial no pilar designado "justiça e assuntos internos" (art. "K.1” do Tratado).

No mesmo documento foi criada a EUROPOL (European Police Office - Agência Européia de Policia), centro europeu de combate à criminalidade transnacional (art. "k.1.9." do Tratado). Enquanto órgão comunitário, não visa substituir o poder de polícia dos Estados membros, carecendo de força executiva. Seu objetivo é, na realidade, coordenar o intercâmbio de informaçóes sobre atividades criminosas na UE, especialmente aquelas consideradas graves, como terrorismo, tráfico de drogas e crime organizado, e promover açóes conjuntas entre as polícias nacionais ${ }^{26}$.

Na primeira reforma da UE (Tratado de Amsterdã, de 1997), o controle comunitário de fronteira externa foi colocado como um objetivo fundamental (art. "b" do Tratado). As questôes referentes à liberdade de locomoção, antes integradas a um pilar intergovernamental

\footnotetext{
${ }^{25}$ ATGER, Anaïs Faure. Op. Cit., p. 07.

${ }^{26}$ Conforme ARTURI, Carlos S. Movimentos Antiglobalização, Terrorismo e Cooperação Interestatal em Segurança Interna na União Européia e na América do Sul. Paper de apresentação do Congresso de 2009 da LASA (Associação de Estudos Latino-Americanos) apresentado em junho de 2009, p. 12.
} 
passam a fazer parte do pilar comunitário, aperfeiçoando-se a integração na área. Inaugura-se uma política única européia de vistos, asilo, imigraçáo e movimentos de pessoas no espaço europeu de "liberdade, justiça e segurança" (Título IV do Tratado).

Em outubro de 1999, reuniu-se, em Tampere, Finlândia, o Conselho Europeu, órgão composto pelos chefes de governos dos membros da UE e responsável pelo planejamento das estratégias de integração. Naquela ocasião, a preocupação com a fiscalização fronteiriça, dentro do cenário instaurado pelo Tratado de Amsterdã, tornou-se evidente. Entendeu o Conselho Europeu pela "necessidade de uma gestão mais eficaz dos fluxos migratórias em todas as suas fases".

A cúpula de Tampere também lançou as bases para o EUROJUST (European Union's Judicial Cooperation Unit - Unidade de Cooperação Judicial da Uniáo Européia). Criada aos moldes da EUROPOL e com funcionamento a partir de 2002, a agência visa à cooperaçáo entre promotores e magistrados nacionais na persecução e extradição em crimes transnacionais.

A agenda anti-terrorista pós-onze de setembro acelerou a institucionalizaçáo securitária da migração e movimentação de pessoas. Na reunião de Laeken, na Bélgica, o Conselho Europeu declarou a necessidade da UE em criar um acordo institucional sobre cooperaçáo entre serviços nacionais de controle de fronteiras externas, de modo a estabelecer um mecanismo comunitário comum ${ }^{27}$. Na mesma reunião foi lançado o projeto do "Mandado de Detençáo Europeu", que consiste na desburocratização da captura de criminosos, podendo ser cumprido um mandado expedido por juiz nacional em qualquer parte do território da UE, sem a necessidade de procedimento de extradição.

Nas reuniôes posteriores do Conselho Europeu, maturou-se a idéia de criação de um órgão comunitário de controle de fronteiras externas. Os Estados inicialmente rechaçaram a criação de uma polícia de fronteira única, pois interferiria nas prerrogativas de soberania. Sendo assim, nos moldes da EUROPOL e EUROJUST, foi fundada, em 2004, a FRONTEX,

\footnotetext{
${ }^{27}$ BERTOZZI, Stefano. Op. Cit., p. 4.
} 
"agência para a gestão de cooperação operacional nas fronteiras externas dos Estados membros da UE”, com sede em Varsóvia, Polônia.

A FRONTEX é responsável por dar treinamento e ajudar nas trocas de informaçóes de entidades nacionais de controle de fronteira. $\mathrm{O}$ objetivo é dar suporte, e não substituir, às guardas nacionais no desempenho de suas atribuiçóes, especialmente em áreas de risco, que necessitam do aumento da capacidade de vigilância. Para isso, implementou-se o Rapid Border Intervention Teams - RABIT (“Equipe Rápida de Intervenção de Fronteira”), grupo multinacional de agentes de fronteira utilizado em situaçóes de emergência envolvendo ingresso ilegal em massa de pessoas na $\mathrm{UE}^{28}$.

Com a implementação de um sistema de vistos comum a partir de Schengen, foi criado, em 2004, o "Visa Information System" (VIS), sistema de informação complementar ao SIS. Trata-se de um banco de dados de informaçóes, incluindo biométricas, sobre nacionais de terceiro países que pleiteiam ingressar legalmente na UE. De maneira similar, há também o EURODAC, que mantém informaçóes de impressão digital sobre requerentes de asilo.

Em 2005, países europeus assinaram a Convenção de Prüm, com o objetivo de reforçar os controles securitários no combate ao "terrorismo, criminalidade transfronteiriça e imigração ilegal”. Assinado fora da UE, tinha como objetivo flexibilizar as legislaçóes nacionais sobre o controle de dados sigilosos (de europeus e não europeus) referentes à identificaçáo pessoal, como impressões digitais e material genético (DNA). Outras questóes dispostas referem-se o uso de força policial dentro de aeronaves em vôos internacionais, criaçáo de equipes de patrulhamento conjunto e ingresso autorizado de autoridades armadas nacionais no território vizinho em caso de perseguição contínua de ameaças (hot pursuit). Assim como Schengen, foi integrado posteriormente ao direito comunitário.

Nos últimos anos, destaca-se, dentro de um cenário de constante securitização institucional, o Tratado de Lisboa (2007), que aboliu a estrutura de pilares, unindo de uma vez por todas, sob o arcabouço comunitário, os assuntos de imigração e polícia. Outro recente

${ }^{28}$ Ibid., p. 15. 
documento refere-se ao novo regime de tratamento de imigrantes ilegais (Diretiva $\mathrm{n}^{\mathbf{o}}$ 2008/115/CE) que prevê a expulsão forçada e a institucionalização de campos de detenção, que permitem a prisão administrativa de até seis meses.

\subsection{Práticas Comunitárias e Estatais de Securitização}

Observa-se, com a securitização da liberdade de locomoção, uma sucessão de práticas repressivas, que desafiam, de maneira contraditória, os princípios democráticos que a UE afirma defender.

No que tange a fiscalização das fronteiras externas, houve, nos últimos anos, um considerável aumento no orçamento da FRONTEX. Verdadeiras operaçóes militares foram conduzidas, destacando-se as realizadas nas Ilhas Canárias (Operação HERA) e Mediterrâneo (Operaçáo POSEIDON). Carrera é bastante crítico em relação à atuação da agência européia de fronteiras, que age basicamente como um instrumento de contenção da migração oriunda da África Subsariana. Conforme relato do autor, na Operação HERA, que contou com apoio militar de governos africanos, a FRONTEX montou uma equipe de fiscalização na costa da África, passando a prender "imigrantes irregulares" antes mesmo de saírem de seu território e entrarem no território da UE, situação que beira o absurdo ${ }^{29}$.

Bigo aponta uma grande contradiçáo na fiscalização das fronteiras externas. Em locais de fácil fiscalização, como aeroportos, as verificaçôes são feitas de maneira rigorosas e desproporcionais. Trata-se de uma ação simbólica que visa apresentar para opinião pública o comprometimento do governo em combater os fluxos migratórios, causadores, na visão dos políticos conservadores, dos problemas econômicos e sociais da Europa. Enquanto isso,

${ }^{29}$ CARRERA, Sergio. The EU Border Management Strategy: FRONTEX and The Challenges of Irregular Immigration in the Canary Islands. Disponível em: <www.ceps.eu>. Acesso em 20.06.2011, p. 25. 
milhares de quilômetros de fronteira terrestre e aquática não são policiados devido ao alto custo $^{30}$.

No que diz respeito às fronteiras internas, na qual o Acordo Schengen previa a diminuição de fiscalização, não houve desecuritização dos países membros da UE, mas o oposto. O fim das fronteiras não foi bem digerido pelas naçóes européias, visto que não estavam preparadas para abdicar de uma das atribuiçóes mais básicas da soberania estatal. Sendo assim, como compensaçáo pela proibição dos tradicionais postos de alfândega, passam a investir na força policial ${ }^{31}$, estabelecendo uma série de equipes de patrulhamento com atuaçáo em todo o território nacional e detentoras de amplos poderes.

Atger menciona uma série de exemplos que sustentam tal argumento. A Alemanha incorporou os antigos oficiais de fronteira à polícia federal, aumentando, consequentemente, seu efetivo na fiscalização interna. A autora também menciona a prática crescente da policia alemã em conduzir buscas em carros de poloneses sob o argumento do aumento da criminalidade transfronteiriça desde a ascensão do Leste Europeu na UE. Prisóes e outras situaçóes de controle policial passaram a ser justificadas em pequenas infraçóes, como não uso de um "kit" de primeiros socorros previsto para os veículos alemães 32 .

Outro exemplo de securitização ocorreu na República Checa. Como Schengen impede que fique estacionada na fronteira, a polícia checa passou a fiscalizar locais tradicionalmente freqüentados por imigrantes, como estações de trem e albergues ${ }^{33}$.

A burocracia também é utilizada como elemento de securitização das fronteiras internas. Os Estados passaram a exigir uma série de documentos de identificação, antes inexistentes na Europa. Se outrora o viajante era consultado apenas quando cruzava a fronteira, agora, pode ser solicitado a se identificar a qualquer momento, sob pena de ser expulso do território.

\footnotetext{
${ }^{30}$ BIGO, Didier. Op.Cit., p. 581.

${ }^{31}$ BUZAN, Barry; WAEVER, Ole. Op. Cit., p. 359.

${ }^{32}$ ATGER, Anaïs Faure. Op. Cit., p. 07.

${ }^{33}$ Ibid., p. 11.
} 


\section{Consideraçóes Finais}

Por tudo apresentado, algumas conclusóes parciais merecem ser feitas. Os processos de securitização enfrentados no CRSE são originários de sua própria evolução e natureza. $\mathrm{O}$ movimento pendular de alternância de centralizaçáo versus fragmentação do complexo culminou no derradeiro modelo centralizado: a Uniāo Européia. No entanto, apesar do relativo sucesso do modelo comunitário, uma vez que praticamente eliminou a possibilidade de guerra entre as naçóes européias, formando uma "comunidade de segurança", o medo de fragmentação persiste, incrementado pela própria natureza cíclica da história do continente europeu.

Sendo assim, a UE securitiza processos sociais não militares, retoricamente classificados como ameaças, de forma a legitimar a sua própria existência, vinculando-se a proteçáo dos cidadãos europeus. A escolha pela migração chega ser um pouco óbvia, visto que o repúdio às culturas consideradas "exóticas", baseada em critérios étnicos e religiosos, ajuda na formação de uma identidade européia.

Para assegurar a condução dessa política, institucionaliza-se, no ambiente comunitário, um conjunto de mecanismos repressivos, que envolvem acesso a dados sigilosos, incluindo informaçóes biométricas, e controle rígido das fronteiras externas européias.

Misturam-se, propositalmente, questôes de fluxos de pessoas com a proliferação da criminalidade transnacional, de modo a usar força policial para empreender uma verdadeira guerra à imigração. Os Estados europeus que ainda não se adaptaram a Schengen e continuam controlando internamente suas fronteiras de maneira dissimulada contribuem para essa realidade. 
No que diz respeito ao controle fronteiriço externo, observa-se que existe um tendência para a militarizaçáo cada vez forte, podendo converter, no futuro, a FRONTEX em uma polícia (ou exército) europeu de controle de fronteira.

É claro que seria temerário realizar um exercício de futurologia, mas com os elementos apresentados no trabalho, pode-se concluir que existe uma tendência crescente da UE em securitizar os problemas de fronteiras. O risco está na formação de um "Estado de exceção permanente", no qual há uma forte interferência estatal nas liberdades (como de locomoção), em prol da proteção da integração européia. Nesse passo, questiona-se se os cidadãos europeus estão dispostos a serem vigiados constantemente, seja por meios tecnológicos como por agências comunitárias de segurança, com objetivo de impedir o retorno à temida fragmentação européia. 


\section{Referências Bibliográficas}

ATGER, Anaïs Faure. The Abolition of Internal Border Checks in an Enlarged Schengen Area Freedom of movement or a web of scattered security checks? Research paper number eight. Disponível em: <www.ceps.eu>. Acesso em 20.06.2011.

BALI, Sita. Population Moviments. In: WILLIAMS, Paul D. Security Studies: an introduction. New York: Routledge, 2005.

BERTOZZI, Stefano. Schengen: Achievements and Challenges in Managing an Area Ecompassing 3.6 million km². Disponível em: <www.ceps.eu>. Acesso em 20.06.2011.

BIGO, Didier. Immigration Controls and Free Movement in Europe. International Review of The Red Cross, v. 91, n. 875, Genebra, set. 2005, p. 579-591.

BUZAN, Barry; WAEVER, Ole. Regions and Powers: The Structure of International Security. Cambridge: Cambridge University Press, 2003.

CARRERA, Sergio. The EU Border Management Strategy: FRONTEX and The Challenges of Irregular Immigration in the Canary Islands. Disponível em: <www.ceps.eu>. Acesso em 20.06.2011.

DEUTSCH, Karl, et al. Political Community and the North Atlantic Area. In: International Political Communities: An Anthology. New York: Doubleday and Company, 1966.

RUDZIT, Gunther. O debate teórico em segurança internacional: mudanças a frente do terrorismo? Civitas, v. 5, n. 2, Porto Alegre, jul. / dez. 2005, p. 297-323.

SCHUMAN, Robert. Declaration of 9 May 1950. Disponível em: < http://europa.eu/abc/symbols/9-may/decl_en.htm>. Acesso em: 20.06.2011. 